\title{
Vasectomy Contraception Method in the Area of Bulili Community Health Center at City of Palu
}

\author{
Rosmala Nur ${ }^{1}$, Muh. Ryman Napirah ${ }^{2}$, Nafilah $^{3}$, Radiah $^{4}$, Nurhaya S. Patui ${ }^{5}$, \\ Larasati $^{6}$, Dilla Srikandi Syahadat ${ }^{7}$, Pitriani ${ }^{\star, \dagger, 8}$ \\ ${ }^{1}$ Biostatistic, Family Planning and Demography Department \\ ${ }^{2}$ Administration and Health Policy Department \\ ${ }^{3}$ Biostatistic, Family Planning and Demography Department \\ ${ }_{4}^{4}$ Biostatistic, Family Planning and Demography Department \\ ${ }^{5}$ Biostatistic, Family Planning and Demography Department \\ ${ }^{6}$ Biostatistic, Family Planning and Demography Department \\ ${ }^{7}$ Epidemiology Department \\ ${ }^{8}$ Environmental Health Department Public Health Faculty Tadulako University, Palu City Indonesia
}

DOI: https://doi.org/10.15520/jcmro.v2i02.131

Accepted 24-02-209; Received 17-02-2019; Publish Online 25-02-2019

\author{
Reviewed By: \\ Kouakou Egnon \\ Department: \\ Reviewer/CMRO
}

\begin{abstract}
Vasectomy method has $99 \%$ success in preventing pregnancy. Among 13 community health centers in 2017, the widest number of vasectomy contraception users recorded in Bulili Community Health Center with 37 people $(57,81 \%)$. The studi aims to discover of several factors of contraception use, such as education, knowledge, and family support. This research is a descriptive quantitative. The sample of this research is 37 men, particularly husbands, who are older than 35 years old and have 2 children. In collecting the sample, this research uses total sampling method. The data collection method is done by observation and interview. Furthermore, the obtained data are analyzed statistically by showing frequency distribution in each variable. The research showed that vasectomy contraception based on education $(64,9 \%)$, knowledge $(89,2 \%)$, and family support $(94,6 \%)$ in this area is good. Consequently, citizens are expected to willingly accept information from health worker related to men's KB.
\end{abstract}

Key words: Contraception-Vasectomy-Method

\section{INTRODUCTION:}

Vasectomy is a method of permanent family planning (KB) for men who do not want to have children again. Client must carefully consider to do this decision. Vasectomy method is an easy and safe procedure and it only needs a few minutes to be done in a hospital or clinic KB which standardize to run an easy surgery. This method is only effective after 20 times ejaculation or three months after the procedure. Before the mentioned time, another barrier (condom) is needed. In general, vasectomy does not has any long-term side effect and it does not affect sexual ability or satisfaction [1] .

According to National Population and Family Planning Board (BKKBN) in 2016, there are $78,2 \%$ or 529.095 cou-

\footnotetext{
* Corresponding author.

$\dagger$ Email: pitrianiarifinkl07@gmail.com
}

ples in reproductive age (PUS) in Central Sulawesi which follow all methods of KB [2] . The widest number of PUS which using vasectomy is found in Donggala Regency with 372 people, the second one in Parimo Regency with 241 people, the third rank is found in Poso Regency with 150 people, the fourth widest PUS is found in Sigi Regency with 106 people, and the fifth rank found in Buol Regency with 70 people. Meanwhile, the city of Palu as the capital city of Central Sulawesi places in the sixth rank with 64 people. Moreover, the target of vasectomy contraception user in Palu is 100 people per year [3] .

Men's low participation in KB is caused by various factors. Based on several studies, the causal factors of men's low participation in KB are: (1) limited option/type of men's contraception, (2) KIE and counseling target tends for women, (3) provider which has not yet optimal in giving men contraception service, (4) social culture and political 


\section{Vasectomy Contraception Method in the Area of Bulili Community Health Center at City of Palu 91}

support as well as operational which still limited and consider that KB, reproduction health, mom and child health are all the matters of women, (5) lack of awareness and knowledge of men in using contraception. Besides, belief or religion is added as influence factors. In 1979, Indonesian Council of Ulama (MUI) states that vasectomy is not accepted as contraception instrument and in 2009 MUI publishes a fatwa haram for vasectomy. Vasectomy is stated as haram (forbidden) because it is done by cutting sperm duct and it is considered as permanent sterilization. Thus, it contradict with Islam law. Nevertheless, in July 2012, MUI states a new fatwa that vasectomy is permitted (mubah) [16]. This amendment happens due to the evidence that vasectomy is not permanent sterilization because for those who still want a child, they can ask for recanalization or reconnection of sperm duct to redress the function [1] .

Based on the data of Palu Public Health Office in 2016, there are 61.229 couples in productive age. The number of vasectomy user in Palu is $75 \%$ from 13 Community Health Centers. In 2017, the widest number of vasectomy user is in Bulili Community Health Center with 37 people or $57,81 \%$. Compared to the target of vasectomy contraception in Palu, 100 people per year, Bulili community health center has a quite high number of vasectomy user [4] . Therefore, this research aims to know about how is the use of vasectomy method in Bulili area, the city of Palu.

\section{METHODS:}

This research is quantitative research with descriptive approach. This research is conducted on July-August 2018 in Bulili community health center, South Palu Subdistrict, the City of Palu. The Sample in this research is the husbands who are older than 35 years old and have 2 children or more. Total sampling is used to collect the sample of 37 respondents.

\section{Operational Definition and Objective Criteria}

1. Education factor, the last education of respondent with objective criteria divided as Adequate or Inadequate.

2. Knowledge factor, the knowledge in using vasectomy contraception with objective criteria divided as Poor and Excellent.

3. Family support factor, the support in using vasectomy contraception with objective criteria divided as Less support and Support.

\section{Data Collection}

The collected data in this research are primary and secondary data which are obtained from questionnaire.

\section{RESULT:}

\section{Education}

Respondent distribution based on education may be seen as follows:
Table 1. Distribution Based on Education in Bulili Community Health Center Area of South Palu Subdistrict, the City of Palu

\begin{tabular}{lll}
\hline Education & Frequency & Percentage \\
Inadequate & 13 & 35,1 \\
Adequate & 24 & 64,9 \\
\hline Total & 37 & 100,0 \\
\hline \multirow{2}{*}{ Source: Primary Data, 2018 }
\end{tabular}

Based on Tabel 1, it can be seen that the largest number of respondent's education is categorized as adequate with 24 people $(64,9 \%)$. Meanwhile, the smallest number of respondent's education or categorizes as inadequate with 13 people $(35,1 \%)$.

\section{Knowledge:}

Respondent distribution based on knowledge in using vasectomy method can be seen in the table below:

Table 2. Distribution Based on Knowledge in Bulili Community Health Center Area, South Palu Subdistrict, the City of Palu

\begin{tabular}{lll}
\hline Knowledge & Frequency & Percentage \\
Poor & 4 & 10,8 \\
Excellent & 33 & 89,2 \\
\hline Total & 37 & 100,0 \\
\hline \multicolumn{2}{l}{ Source: Primary Data, 2018 }
\end{tabular}

Based on Table 2 , it is known that the largest number of respondent's knowledge with excellent category is 33 people $(89,2 \%)$, while the smallest number with poor category is 4 people $(10,8 \%)$.

3. Family Support:

Respondent distribution based on family support in using vasectomy contraception can be seen in the tabel below:

Table 3. Distribution Based on Family Support in Bulili Community Health Center area, South Palu Subdistrict, the City of Palu

\begin{tabular}{lll}
\hline Family Support & Frequency & Percentage \\
Less Support & 2 & 5,4 \\
Support & 35 & 94,6 \\
\hline Total & 37 & 100,0 \\
\hline
\end{tabular}

Source: Primary Data, 2018

Based on the Tabel 3, it can be seen that the highest number of respondent's family support categorizes as support with 35 people $(94,6 \%)$, while the smallest number categorizes as less support with 2 people $(5,4 \%)$.

\section{DISCUSSION:}

\section{Education in Vasectomy Contraception Use}

Education is one of the factors which influence knowledge and behavior towards contraception method. The more educated people, the more they give rational response and may adjust themselves toward social change rather than 
those who have less education. Furthermore, those who have higher education can directly or indirectly adjust themselves toward the social changes related to Family Planning (KB) [5] .

In tabel 1, it shows that the largest number of respondent's education categorizes as adequate is 24 people $(64,9 \%)$. As it is known that the higher people's education will affect respondent's knowledge in which it is in line with Rizaly et al theory [6] . The higher education level will obviously affect someone's personality in giving opinion, thought, behavior, and they tend to be more independent and rational in taking particular decision or action. Moreover, the factor will directly influence someone's knowledge related to their live orientation such as planning their family.

Based on the result of this research, it is obtained 13 respondents or $(35,1 \%)$ with less education. According to Erliani [7] respondent who wants or does not want to use vasectomy method is not influenced by high or low formal education level owned by the respondent.

According to Notoadmojo [8], education is one of the factors which influence someone's knowledge and behavior toward vasectomy method. The argument is in line with a research by Anita et al [9] which states that education level and contraception selection are related to each other. Education with mindset, perception, and behavior of citizens is certainly significant. It means the higher someone's education level, the more rational his/her mindset in taking various decisions. It is also supported by a research by Indah [10] that there is relationship between education level and contraception selection. Similar research also conducted by Citra et al [11] which shows the relationship between education level and contraception instrument choice of KB acceptor at RW 03 Kedung Cowek Subdistrict, Surabaya.

PUS women who have high education level will choose MKJP contraception since they have good knowledge about benefit and risk of contraception instrument. Therefore, they would choose safe, practice, and long-term contraception. Similar research by Bhandari et al [12] states that the use of contraception by women and their husband who have high education is in amount of $65,6 \%$ related to contraception use in Nepal in which possibly using modern contraception rather than those who do not have high education.

However, the result is different with a research by Afsari [13] which states that education level is not related to contraception selection. It can be influenced by characteristic and the number of respondent in each research. imilar research is also conducted by Lubis [14] that states education does not influence decision to use vasectomy.

2. Knowledge in Using Vasectomy Contraception

According to Notoadmojo [8] knowledge is a result of knowing in which it happens after someone conduct some sensing on particular object. This sensing happens through human sensor such as vision, hearing, smelling, tasting, and touching. Most of human's knowledge is obtained through eyes and ears. Knowledge or cognitive is an important domain to shape someone's behavior [15] .Table 2 shows respondent's knowledge about contraception use is considered as excellent with 33 people $(89,2 \%)$. The knowledge of KB's acceptor is closely related with contraception tool since through a good knowledge on contraception method, obviously it will change acceptor's point of view in choosing the most effective and suitable contraception. Good knowledge about contraception tool will prevent a mistake in choosing suitable contraception [16] (Marhaeni, 2010).

Based on the result of questionnaire, the average of respondents knows about vasectomy contraception, the benefit, and its weaknesses, also any requirements of vasectomy contraception. The larger someone's knowledge, so the higher someone's awareness toward KB. According to the interview, respondents who want to do vasectomy are often getting information on Men Surgery Method (MOP) from their colleague. Besides, it influences respondent's knowledge level on vasectomy by the existence of socialization from health center officer. Several respondents said that vasectomy increases their sexual desire, increase spirit for working since sperm is changed into energy in the body. Respondents also admitted that they feel enough to have 3 children and their birth gaps are to close. If a husband has already know a good knowledge about men's KB, so that there will be no regret after the procedure conducted and consider that it is a safe and simple procedure.

From the result of this research, respondents with not-avery-good knowledge are found in the number of 4 people $(10,8 \%)$. The level of knowledge about contraception instrument indicates that someone tends to have open mind in receiving information. Meanwhile, respondents who have lesser knowledge indicate that they are less open in receiving the related information [17] .

The result of this research is in line with a research by Erliani [18] (2012) that shows a husband with a good knowledge has possibility 3,316 times higher to do Men Surgery Method (MOP) than they who do not have good knowledge. It also in accordance with a research by Sood et al [19] that states $42 \%$ respondents have a good knowledge and approve sterilization because of their knowledge about sterilization benefit. imilar research is conducted by Marhaeni (2010) which states that there is significant influence between knowledge and contraception selection by KB acceptor.

These researches are not in accordance with a research by Ares [18] that there is no significant relation between knowledge and vasectomy contraception. It happens because lack of socialization and information from health officer in Medan Selayang Subdistrict. Even there are people who do not know vasectomy contraception (men surgery method)

\section{Family Support in Vasectomy Contraception} Use

Family support is the most important factor in helping people to settle a problem. Family support will give confidence and motivation to face a problem and increase life satisfaction. In this case, family must be involved in education process so that family may fulfill patient's needs by knowing when they must seek for help and support patient to obey a treatment [20] . 


\section{Vasectomy Contraception Method in the Area of Bulili Community Health Center at City of Palu 93}

Table 3 shows respondents' family support is 35 people (94,6\%). An approval from a wife/family is considered as a key to decide vasectomy use. More than $50 \%$ from the couple in Tanzania whose husband uses vasectomy method, say that wife approval is one of the factors to take this decision [14] .

Based on the result of questionnaire, most of family suggests to use vasectomy, family gives information about vasectomy, approves to conduct vasectomy, and does not worry to let respondents use vasectomy contraception. The result shows that wives who have approve their husband to do vasectomy are they who do not find a proper contraception for them. Besides, other conditions force them to do vasectomy since the wives cannot use tubectomy method. Other respondents state that the reason why their wives let them is because of their wives' uterus condition that does not support to pregnant again.

From the result of this research, it is also obtained the number of respondents who are not supported by their family in the number of 2 people $(5,2 \%)$. According to Puspitasari [21], low and high family support will correlate with low and high participation PUS to do KB. Through family support, PUS becomes more excited to participate in $\mathrm{KB}$ program.

According to Notoadmodjo [8], family support refers to social support that is regarded by family member. Family support (husband/wife) sees that someone who supports us will be ready to give help if it is needed. The core family or relative functions as support system for their member. It is in line with a research by Indrayana [22] that shows significant relation between wives support and husband participation in $\mathrm{KB}$.

Wives' response toward vasectomy method which will be conducted by their husbands is a form of support. Wives response may be positive or negative depends on knowledge, beliefs, behavior and role model. It is in accordance with a research by Manurung [23] that states wives' response has relation in choosing vasectomy as men's contraception instrument. This research also in line with a research by Lubis [14] that wives' support has significant role in deciding vasectomy use. Timothy [24] also states that there is signifcant relation between family support and contraception use in Kenya's rural area.

Nevertheless, this research is not in accordance with a research by Afsari [13] which states that family support in choosing contraception is not related due to lack of information which owned by family about reproduction health especially on contraception instrument. Many wives do not let their husband to do vasectomy because they think contraception lessen sexual pleasure.

\section{CONCLUSION}

The conclusion of this research is vasectomy use in Bulili Community Health Center in South Palu Subdistrict, the City of Palu based on education, knowledge, and family support is already well enough in which the result is more than $50 \%$. In order to do vasectomy and make it as an option in citizen especially in the City of Palu, it is expected that government especially health officer may give wide information about vasectomy, and citizen may open and accept information from health center related to men's KB and mitigate negative stigma that vasectomy is same with castration.

\section{REFERENCES}

[1] hani Aini Q. Vasectomy in Babakan Sari Village. Jakarta; 2013.

[2] BKKBN. Family Planning And Reproduction Health. Central Sulawesi; 2016.

[3] [3] Central Sulawesi Public Health Office. Office; 2016.

[4] [4] The City of Palu Health Office. Palu: The City of Palu Health Office; 2016.

[5] Ismail S. The Relation Between Education Level and Productive Couple (PUS); 2014.

[6] Factors Associated with Contraceptive Injection Method Selection in Mattoangin Sub-district, Mariso District, Makassar City. MKMI JOURNAL. 2013 9;p. 176-183.

[7] Erliani D. Determinant Use of Men Surgery Method; 2015. North Sumatera.

[8] Notoatmodjo S. Health Promotion and Behavior. Jakarta: Rineka Cipta; 2012.

[9] Anita L, Kusmiati RD. The Factors which associated with Contraception Selection of Productive Age Couple in Damau. Community Health Center, Talaud Regency Midwife Scientific Journal ISSN: 2339-1731 Midwifery. 2014;

[10] Indah. Analysis of Factors which Associated with LongTerm Contraception Selection (MKJP) of KB's Women Acceptor in Banyubiru Subdistrict, Semarang Regency. Unnes Journal of Public Health. 2012;

[11] Mayasari AEC. The Relation between Education Level and the Number of Child with Contraception Selection of KB Acceptor. The result. Nursery, The College of Health. 2017;

[12] Bhandari PCT. Study of factors affecting contraceptive use among married women of reproductive Age. Journal of College of Medical Sciences-Nepal. 2013;2013(9):4-24.

[13] Afsari. Contraception Use on Teenage Girl in Indonesia. Center of Research and Development of Community Health Services Health Research. 2017 12;45(4). 257 - 266.

[14] [14] Lubis, Ade Yus Muliani Lubis. Public Health Faculty, North Sumatera University; 2010.

[15] Rizkitama FI. [15] Afnita Ayu. vol. 2011; 2015.

[16] [16] Indonesian Council of Ulama. Jakarta: Secretariat of Indonesian Council of Ulama (MUI; 2009.

[17] Dewi MW. Theory and Measurement of Human Knowledge, Behavior, and Attitude. Jakarta: Nuha Medika; 2010.

[18] Ares. The Relationship Between Knowledge About Contraception Instrument with Behavior in Choosing Contraception of KB Acceptor. vol. 12; 2014.

[19] Aditya Sood, Parika Pahwa. 2014. Vasectomy: a study of attitudes, beliefs, knowledge and practices among literate men in Punjab, India. International Journal of. 0;.

[20] Awareness of married men on vasectomy and its adoption. vol. $4 ; 2016$.

[21] Family Support in Family Planning Participation of Reproductive Age Couple in Argomulyo Sedayu Village; 2015.

[22] Factors which Influence Vasectomy Contraception Selection, I; 2013.

[23] Manurung SS. Analysis of Factors which Influence Husband in Choosing Vasectomy in Medan Marelan Subdistrict 2012. 


\section{$94 \quad$ Rosmala Nur et al.}

Thesis of. Public Health Study Master, Postgraduate Program, North Sumatera Univeristy; 2012.

[24] Okech DTKMTC. Contraceptive Use among Women of Reproductive Age in Kenya's City Slums. International Journal of Business and Social Science. 2011 1;2(1). 